\title{
Morphological Characterization and Chemical Composition of Fruits of the Traditional Croatian Chestnut Variety 'Lovran Marron'
}

\author{
Igor Poljak1, Nada Vahčić2, Milica Gačić ${ }^{2}$ and Marilena Idžojtićc* \\ ${ }^{1}$ University of Zagreb, Faculty of Forestry, Svetošimunska 25, HR-10000 Zagreb, Croatia \\ ${ }^{2}$ University of Zagreb, Faculty of Food Technology and Biotechnology, Pierottijeva 6, \\ HR-10000 Zagreb, Croatia
}

Received: June 19, 2015

Accepted: February 3, 2016

\begin{abstract}
Summary
'Lovran Marron' is the only known traditional Croatian variety of the sweet chestnut. The objective of this study is to specify qualitative and quantitative morphological characteristics and to analyze the chemical composition of the 'Lovran Marron' fruits as well as to compare them to Marušnjak fruits (trees from the 'Lovran Marron' seed) and fruits from the local natural sweet chestnut population. Seven morphological characteristics were measured: fruit mass, height, width and thickness, scar length and width, and the length of the longest intrusion of the seed coat into the kernel. Eight qualitative characteristics were estimated: embryony, degree of penetration of the seed coat into the kernel, fruit shape, glossiness and colour, kernel colour, hairiness towards the top of the fruit and the existence of longitudinal stripes. 'Lovran Marron' has desirable qualitative and quantitative fruit characteristics. The Marušnjak trees mostly have intermediate morphological traits of fruits in comparison with 'Lovran Marron' and trees from the natural population. 'Lovran Marron' had the smallest mass fractions on average of: $\mathrm{K}, \mathrm{Mg}$, $\mathrm{Ca}, \mathrm{Na}, \mathrm{Mn}, \mathrm{Cu}$ and Fe. The highest mass fractions on average of these macro- and microelements were characteristic of the trees from the natural population. The highest average content of carbohydrates was recorded in the 'Lovran Marron' and the lowest in the fruits from the natural population. The Marušnjak fruits had intermediate water, protein, ash, carbohydrates, and macro- and microelement content. The content of $\mathrm{Cd}$ and $\mathrm{Pb}$ was lower in all samples than the maximum allowed amounts in the sweet chestnut fruits.
\end{abstract}

Key words: Castanea sativa, 'Lovran Marron' fruits, morphological characteristics, chemical composition

\section{Introduction}

The sweet chestnut (Castanea sativa Mill., Fagaceae family) is a noble hardwood growing in the forests of the hilly and mountainous area of the continental and subMediterranean part of Croatia. It is a species providing multiple benefits to man (wood, fruit, honey, tannin, preservation of ecological and landscape values). The last thirty years have seen a gradual return of interest in the growing of the sweet chestnut in South Europe $(1,2)$. The majority of countries in which the European sweet chestnut is grown have their own traditional varieties, obtained through long and hard work, i.e. selection over several centuries (3-14). The best and most widely known cultivars from a nut quality standpoint are the marron type. Marrons are, according to Italian standards, only those cultivars (varieties) of the European sweet chestnut 
with the best quality, large fruits of oblong shape, that have a small scar, light brown colour, and slightly protruding, longitudinal dark stripes, are tasty, easy to peel and rarely have double seeds. The French definition of marrons is similar to the Italian, and it also states that they should have less than $12 \%$ of the fruits with two seeds. Among the best marrons are the Italian cultivars: 'Chiusa Pesio', 'Luserna', 'Val Susa', 'Castel del Rio', 'Marradi' and 'Fiorentino', and French: 'Montagne', 'Sardonne' and 'Comballe' $(5,15)$. However, the growing of traditional varieties is on the decrease, and they are gradually being replaced by new, hybrid varieties (12).

In Croatia, the traditional variety 'Lovran Marron' is grown on private estates in the Lovran surroundings, on the eastern slopes of Mount Učka, where the oldest plantations are several hundred years old. This is the only known traditional Croatian variety of the sweet chestnut. The fruits of this cultivar were exported as early as the 17 th century and in addition to olives, grapevine and sweet cherries, they were one of the crops that had been providing livelihood to the population of the region for centuries. Their production and export peaked in the 19th century, followed by a stagnation in the 20th century, and then partial neglect of the plantations (16). The neglect of the old and lack of new plantations is a major problem, present not only in Croatia but in all Mediterranean countries. The principal causes of this problem are the changes in the way of life of the local population, appearance of the chestnut blight, and in the last few years, of the chestnut gall wasp $(6,17-22)$.

Trees from the marron seed (local name Marušnjak) are grown in plantations together with marrons, but in a small number. On the Mount Učka naturally growing sweet chestnut trees, grafted marron trees as well as Marušnjak trees grow at an altitude between 400 and 700 $\mathrm{m}$ above the sea level. Idžojtić et al. (23) researched the genetic diversity of marron plantations in the Lovran area and determined that $83 \%$ of the trees belong to the same genotype (cultivar), and that MG01 is the dominant genotype ('Lovran Marron' variety).

Studies of the morphological characteristics and/or chemical composition of the fruits for traditional or more recently selected cultivars of the sweet chestnut have been conducted in different countries: Italy (24-29), Spain $(10,30-42)$, Switzerland (43-45), Portugal (46-51) and Turkey (52,53). De Vasconcelos et al. (54) analyzed literature data for Portugal, Spain, Italy and Greece. Studies of the 'Lovran Marron' fruits have not been conducted to date, hence the objective of this study is to specify quantitative and qualitative morphological characteristics, and to analyze the chemical composition of the 'Lovran Marron' fruits.

\section{Material and Methods}

\section{Samples}

Samples of fruits for morphological and chemical analyses were collected in October 2013 in Croatia, on the territory of Mount Učka, located in the bay of Kvarner, near Rijeka. Ten trees of the 'Lovran Marron' (of the most represented genotype MG01), 10 trees grown from the marron seed (Marušnjak), and 10 trees of the natural sweet chestnut population of Učka were sampled. Trees were sampled in an area of $3.5 \mathrm{~km}^{2}$.

\section{Morphological analysis}

In order to conduct the morphological analysis, 30 fruits were collected from each tree, located laterally in cupules. Immediately after the collection, fruit mass was measured, as well as the following morphological characteristics (55): fruit height, fruit width, fruit thickness, scar length, scar width, and the length of the longest intrusion of the seed coat into the kernel (Fig. 1). From the measured characteristics, the following ratios were derived: fruit height/width, fruit thickness/height, fruit thickness/ width, scar width/length, and length of the longest intrusion of the seed coat into the kernel/fruit thickness. In addition to quantitative characteristics, the following qualitative characteristics were estimated using standardized descriptors (56): embryony, degree of penetration of the seed coat into the kernel, fruit shape, fruit glossiness (immediately after opening of cupule), fruit colour and kernel colour. In addition, hairiness towards the top of the fruit $(57,58)$ and the existence of longitudinal stripes on the fruit were assessed (59).

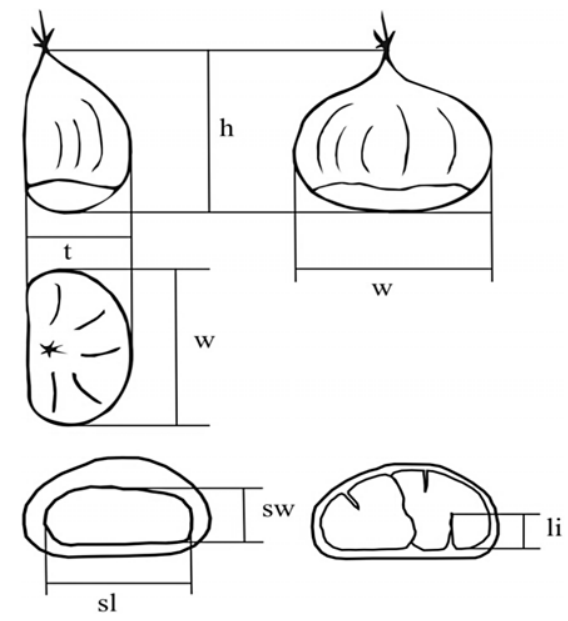

Fig. 1. Measured fruit traits: height (h), width (w), thickness (t), scar length (sl), scar width (sw) and length of penetration of the seed coat into the kernel (li)

\section{Chemical analysis}

Directly after collection, the freshly picked fruits were peeled. The pericarp and seed coat were removed, after which only the edible part of the fruit remained, i.e. the kernel. The cleaned seeds were shredded using a shredding blender (Gorenje, Velenje, Slovenia). From each tree, $100 \mathrm{~g}$ of shredded sample were placed in hermetically closed containers and stored in a freezer at $-20{ }^{\circ} \mathrm{C}$. Water content was determined using the AOAC method 925.40 (60) and ash content according to AOAC method 950.49 (61). The total nitrogen content was detected using the Kjeldahl method and the percentages of nitrogen were transformed into protein content by multiplying by a conversion factor of 5.3 (62). The total fat extraction was performed according to AOAC method 948.22 (63), during 16 
h, using a Soxhlet apparatus (Inkolab, Zagreb, Croatia) and diethyl ether. Carbohydrate content was estimated by subtracting other components using the following formula $(46,47,64,65)$ :

$$
w(\text { carbohydrate })=
$$$$
=100-(w \text { (moisture })+w(\text { protein })+w(\text { fat })+w(\text { ash }))
$$

Macro- and micronutrients $(\mathrm{K}, \mathrm{Ca}, \mathrm{Mg}, \mathrm{Na}, \mathrm{Cu}, \mathrm{Fe}$, $\mathrm{Mn}$ and $\mathrm{Zn}$ ) and toxic metals ( $\mathrm{Pb}$ and $\mathrm{Cd}$ ) were determined by atomic absorption spectrometry using a Varian SpectrAA 220 spectrophotometer (Varian, Mulgrave, Victoria, Australia).

\section{Statistical analysis}

For all of the studied variables, standard descriptive statistical parameters (66) were calculated: arithmetic mean, standard deviation (S.D.) and coefficient of variability (CV). Assumptions of normality were checked using the Shapiro-Wilk test, and the assumption of homogeneity of variance using Levene's test (66). Statistically significant differences among the studied groups of trees were established using the analysis of variance (ANOVA). The differentiation among the studied groups of variables $(\mathrm{Pb}$ and $\mathrm{Cd}$ ) with a skewed and heteroscedastic distribution was verified using the Kruskal-Wallis ANOVA (66). In order to gain insight into the share of individual studied sources of variability in the overall variance (between trees and between fruits within a tree) for the measured fruit characteristics, the restricted maximum likelihood method (REML) was used. The data used in the PC analysis were previously standardized using the z-score method. The specified statistical analyses were conducted using the STATISTICA v. 8.0 statistical program (67).

\section{Results}

The results of the descriptive statistical analysis and the ANOVA are shown in Table 1. The largest fruit mass

Table 1. Descriptive statistical parameters and levels of significance

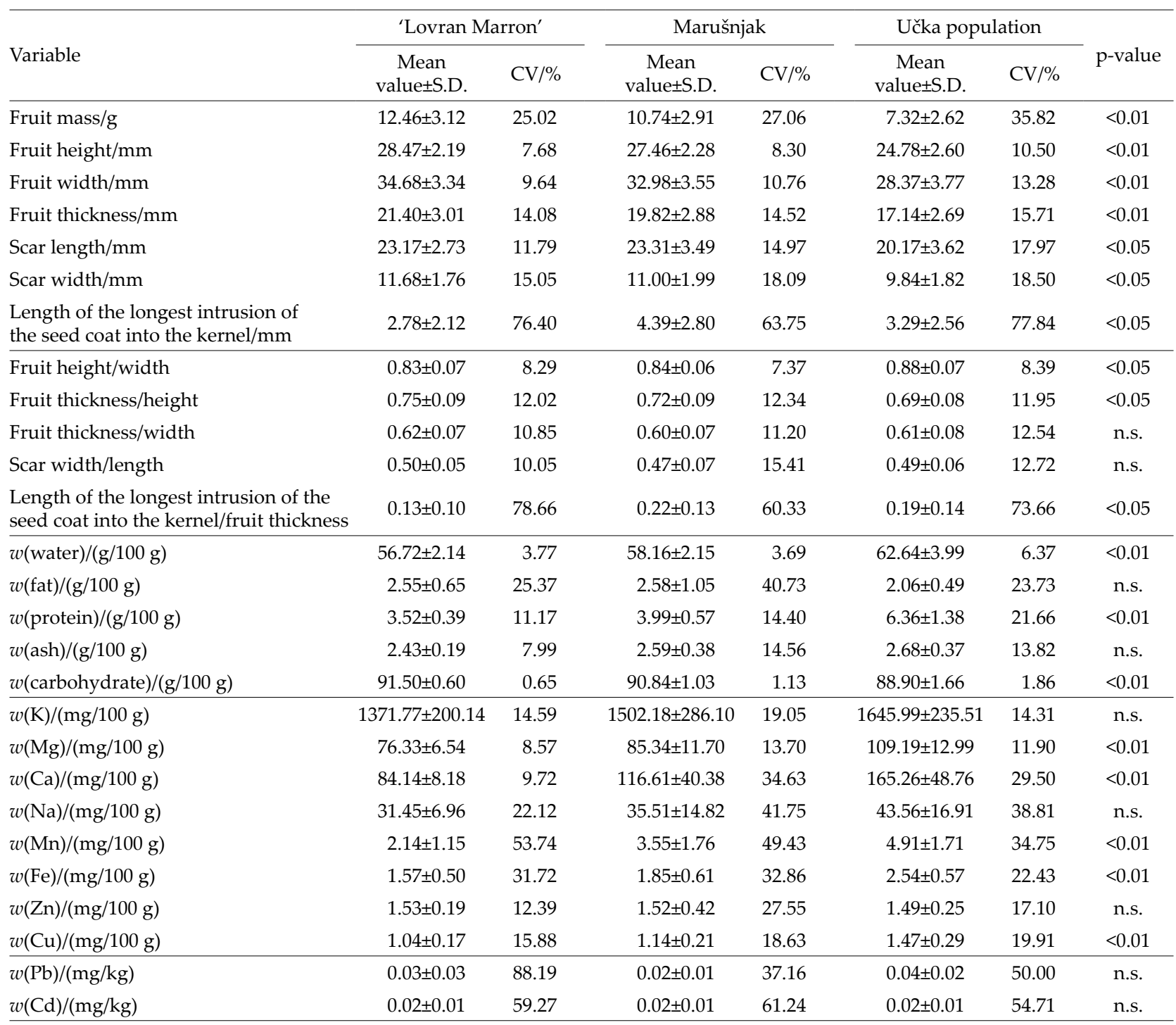

All mass fractions were determined on dry mass basis, except for $\mathrm{Pb}$ and $\mathrm{Cd}$ (on fresh mass basis). S.D.=standard deviation, $\mathrm{CV}=$ coefficient of variability, n.s. $=$ not significant 
on average, and the highest values of fruit height, width and thickness, as well as of scar width were observed in the 'Lovran Marron' trees. The lowest values on average of the same characteristics were typical of the trees from the natural population. Likewise, the shortest scar on average was recorded for the trees from the natural population. Most of the characteristics of Marušnjak fruits were of intermediate value. The shortest length on average of the longest intrusion of the seed coat into the kernel was observed in the 'Lovran Marron', and the longest in the Marušnjak. The studied groups differed at the significance level of 0.01 in fruit mass, height, width and thickness, while at the level of 0.05 this difference was significant for scar length and width, and for the length of the longest intrusion of the seed coat into the kernel.

From the ratio of the fruit height to width it is visible that the fruits are on average wider than high. The smallest ratio on average was characteristic of the 'Lovran Marron' (hight/width=0.83), and the biggest of the natural population (hight/width $=0.88$ ). The average ratio of fruit thickness to height of the 'Lovran Marron' was 0.75, of the Marušnjak 0.72 , and of the trees from the natural population 0.69 . In other words, the fruits of all studied groups were higher on average than they were thick. The ratio of fruit thickness to width in all studied groups was the same. The variables of scar length and width were placed in a mutual relationship, from which it is visible that the fruits of all studied groups had a scar which was on average twice as long as its width. Statistically significant differences $(p<0.05)$ were found for the following characteristics: fruit height/width ratio, fruit thickness/height ratio, and the length of the longest intrusion of the seed coat into the kernel/fruit thickness ratio.

The highest variation coefficients were obtained for the length of the longest intrusion of the seed coat into the kernel and for its relationship with fruit thickness, and the lowest for fruit height and its relationship with fruit width. The highest variability of the majority of morphological characteristics was typical of the sweet chestnut trees from the natural populations, and the lowest of the 'Lovran Marron'.

In addition to different morphological characteristics, the trees of the 'Lovran Marron' also differed from the trees of the natural populations and the Marušnjak in qualitative characteristics (Table 2; 57-59), which are as follows: the fruits are transversally ellipsoid to transversally broadly ellipsoid, reddish brown and shiny, with longitudinal, darker and slightly protruding stripes, medium hairy towards the top. One fruit contains one seed, and the degree of intrusion of the seed coat into the kernel is medium. The colour of the kernel in fresh, raw state

Table 2. Morphological qualitative traits

\begin{tabular}{|c|c|c|c|c|c|}
\hline UPOV number & Trait & Classes & 'Lovran Marron' & Marušnjak & Učka population \\
\hline \multirow[t]{2}{*}{27} & \multirow[t]{2}{*}{ Fruit: embryony } & monoembryonic & 10 & 8 & 8 \\
\hline & & polyembryonic & - & 2 & 2 \\
\hline \multirow[t]{2}{*}{29} & \multirow{2}{*}{$\begin{array}{l}\text { Fruit: penetration of the } \\
\text { seed coat into kernel }\end{array}$} & absent & - & - & - \\
\hline & & present & 10 & 10 & 10 \\
\hline \multirow[t]{3}{*}{30} & \multirow{3}{*}{$\begin{array}{l}\text { Fruit: degree of penetration } \\
\text { of the seed coat into kernel }\end{array}$} & weak & - & - & 2 \\
\hline & & medium & 10 & 5 & 3 \\
\hline & & strong & - & 5 & 5 \\
\hline \multirow[t]{5}{*}{31} & \multirow[t]{5}{*}{ Fruit: shape } & ovoid & - & - & - \\
\hline & & broad ovoid & - & - & 2 \\
\hline & & globose & - & - & - \\
\hline & & transverse ellipsoid & 7 & 6 & 1 \\
\hline & & transverse broad ellipsoid & 3 & 4 & 7 \\
\hline \multirow[t]{2}{*}{34} & \multirow{2}{*}{$\begin{array}{l}\text { Fruit: glossiness (immediately } \\
\text { after opening of cupule) }\end{array}$} & absent & - & - & - \\
\hline & & present & 10 & 10 & 10 \\
\hline \multirow[t]{5}{*}{35} & \multirow[t]{5}{*}{ Fruit: colour } & light brown & - & 1 & - \\
\hline & & brown & - & - & 3 \\
\hline & & dark brown & - & - & 3 \\
\hline & & reddish brown & 10 & 9 & 3 \\
\hline & & blackish brown & - & - & 1 \\
\hline \multirow[t]{2}{*}{38} & \multirow[t]{2}{*}{ Kernel: colour } & white & - & - & - \\
\hline & & cream & 10 & 10 & 10 \\
\hline \multirow{3}{*}{$\begin{array}{l}\text { Not included } \\
(57,58)\end{array}$} & \multirow[t]{3}{*}{ Fruit: hair on torch } & absent & - & - & 4 \\
\hline & & barely visible & 10 & 8 & 5 \\
\hline & & visible & - & 2 & 1 \\
\hline \multirow{2}{*}{$\begin{array}{l}\text { Not included } \\
(59)\end{array}$} & \multirow[t]{2}{*}{ Fruit: stripes } & absent & - & - & 2 \\
\hline & & present & 10 & 10 & 8 \\
\hline
\end{tabular}


is yellowish-white. The biggest diversity of the qualitative characteristics was found in the fruits from the natural population.

The REML method provided insight into the share of individual sources of variability in the overall variance of the measured variables (Table 3). The largest variability was established among the trees of the natural population and the smallest among those of 'Lovran Marron'. On the other hand, the highest variability of the fruits within the same tree was characteristic of the 'Lovran Marron', and the lowest of the natural population.

The results of the descriptive statistical analysis of the chemical composition of the fruits are shown in Table 1. The highest average content of water, protein and ash (in dry matter), as well as the lowest average content of fat and carbohydrates (in dry matter) was found in the trees from the natural population. By contrast, the highest mass fraction of carbohydrates in dry matter on average was found in the trees of the 'Lovran Marron', and the highest content of fat in dry matter on average was found in the trees of the Marušnjak. Statistically significant differences between the studied groups $(p<0.01)$ were found in the content of water, proteins and carbohydrates in dry matter.

The results of the principal component (PC) analysis, which included the measured morphological characteristics and basic chemical composition, show that cumulative variability in the first three PC axes is approx. $81.7 \%$ (Fig. 2), with the expected highest share of the first PC axis of about $55 \%$. The second and third PC axes contribute substantially less to the overall variability, with 17.1 and $9.5 \%$, respectively. It is visible in Table 4 that all of the measured morphological characteristics, with the exception of the length of the longest intrusion of the seed coat into the kernel, are highly positively correlated with the first PC axis, while the mass fraction of proteins and water is negatively correlated. In other words, trees with larger fruits and smaller protein and water content are grouped on the right side of the diagram, while those with smaller fruits and bigger content of proteins and water are grouped on the left (Fig. 2). The components highly correlated with the second PC axis are ash (negatively)
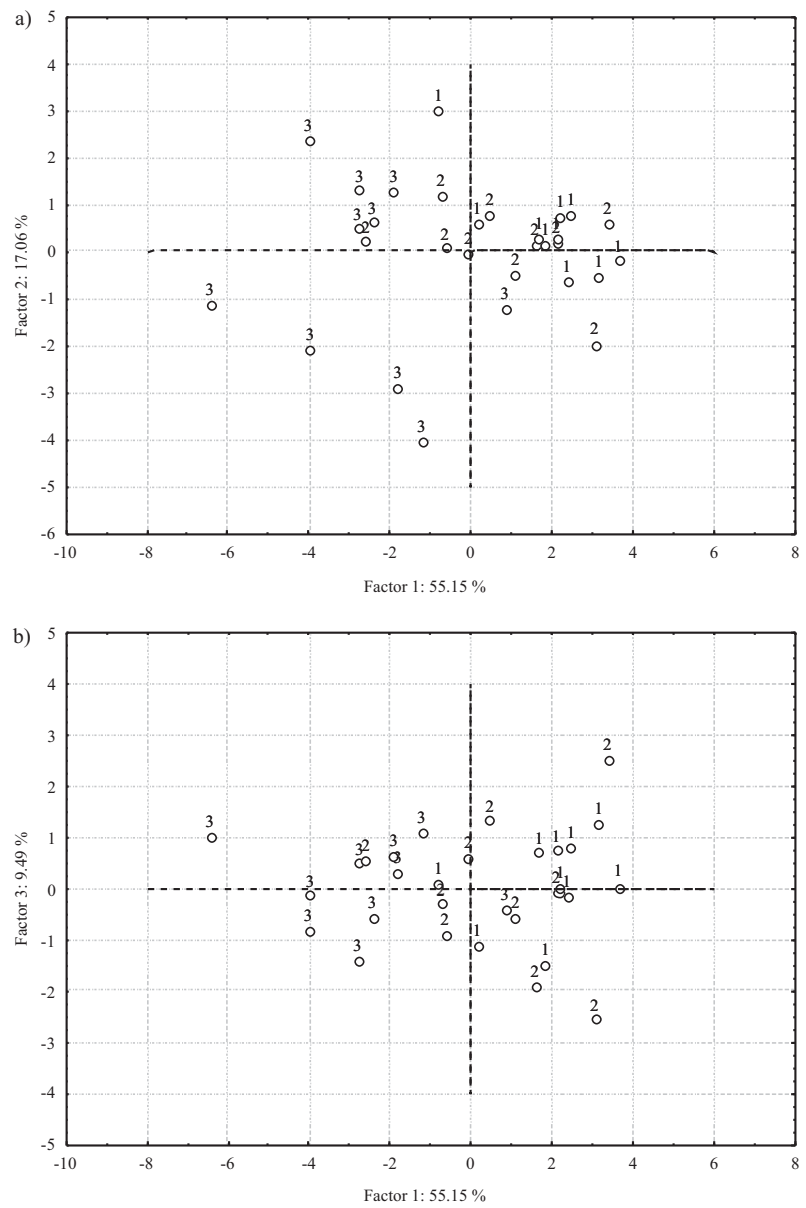

Fig. 2. PC analysis based on the measured fruit traits and basic chemical composition: a) score plot of the chestnut samples projected on the space of PC1 vs. PC2, and b) score plot of the chestnut samples projected on the space of PC1 vs. PC3. (1='Lovran Marron', 2=Marušnjak, and 3=Učka population)

and carbohydrate (positively) mass fractions. The third PC axis is highly positively correlated with the fat content.

Atomic absorption spectrometry was used to establish the mass fraction of eight macro- and microelements, and two toxic heavy metals. The 'Lovran Marron' had the

Table 3. Partitioning of variance by hierarchical level of seven fruit morphological traits

\begin{tabular}{|c|c|c|c|c|c|c|c|c|c|}
\hline \multirow[b]{2}{*}{ Variable } & \multicolumn{3}{|c|}{ 'Lovran Marron' } & \multicolumn{3}{|c|}{ Marušnjak } & \multicolumn{3}{|c|}{ Učka population } \\
\hline & $\begin{array}{l}\text { Between } \\
\text { trees/\% }\end{array}$ & $\begin{array}{l}\text { Fruits } \\
\text { within } \\
\text { tree/\% }\end{array}$ & Residual/\% & $\begin{array}{c}\text { Between } \\
\text { trees/\% }\end{array}$ & $\begin{array}{l}\text { Fruits } \\
\text { within } \\
\text { tree/\% }\end{array}$ & Residual/\% & $\begin{array}{c}\text { Between } \\
\text { trees/\% }\end{array}$ & $\begin{array}{l}\text { Fruits } \\
\text { within } \\
\text { tree/\% }\end{array}$ & Residual $/ \%$ \\
\hline Fruit mass & 51.1 & 40.5 & 8.4 & 61.8 & 29.2 & 8.9 & 73.9 & 16.9 & 9.2 \\
\hline Fruit height & 35.3 & 49.0 & 15.7 & 60.1 & 27.0 & 12.8 & 74.5 & 16.3 & 9.2 \\
\hline Fruit width & 45.9 & 46.6 & 7.5 & 61.7 & 31.9 & 6.4 & 72.5 & 22.0 & 5.5 \\
\hline Fruit thickness & 39.6 & 51.2 & 9.2 & 42.1 & 48.0 & 9.9 & 55.1 & 34.5 & 5.4 \\
\hline Scar length & 41.3 & 47.8 & 10.9 & 61.7 & 31.7 & 6.6 & 72.4 & 21.8 & 5.8 \\
\hline Scar width & 41.4 & 37.7 & 21.0 & 61.7 & 23.3 & 15.0 & 64.3 & 19.5 & 16.2 \\
\hline $\begin{array}{l}\text { Length of the } \\
\text { longest intrusion } \\
\text { of the seed coat } \\
\text { into the kernel }\end{array}$ & 4.0 & 77.5 & 18.5 & 36.1 & 53.3 & 10.6 & 47.8 & 40.4 & 11.8 \\
\hline
\end{tabular}


lowest values on average of: $\mathrm{K}, \mathrm{Mg}$, $\mathrm{Ca}, \mathrm{Na}, \mathrm{Mn}, \mathrm{Cu}$ and Fe. By contrast, the highest mass fractions on average of the said macro- and microelements were characteristic of the trees from the natural population. The highest average content of Zn was measured in the 'Lovran Marron', and the lowest in the fruits from the natural population. The Marušnjak fruits contained intermediate mass fractions of all studied macro- and microelements. According to the results of the ANOVA (Table 1), the studied groups differed in the mass fraction of $\mathrm{Mg}, \mathrm{Ca}, \mathrm{Mn}, \mathrm{Fe}$ and $\mathrm{Cu}$ at the level of significance of 0.01 . The differentiation in the mass fraction of $\mathrm{K}, \mathrm{Na}$ and $\mathrm{Zn}$ was not statistically significant. The mass fractions of detected toxic heavy metals $\mathrm{Cd}$ and $\mathrm{Pb}$ were in all samples below the maximum allowed amounts in the sweet chestnut $(0.05$ and $0.1 \mathrm{mg} / \mathrm{kg}$, respectively). In approx. $50 \%$ of the samples they were below the limit of detection $(<0.01 \mathrm{mg} / \mathrm{kg})$.

The PC analysis of the eight studied macro- and microelements showed that the first three principal components account for $74.5 \%$ of the total variability. The eigenvalues were greater than one for the first three principal components. Factor coordinates of the measured variables based on correlations displaying the degree of association between each of the original variables with each principal component are shown in Table 4 . The first principal component participates in the overall variance with $36.1 \%$ (Fig. 3) and is in highly positive correlation with the content of $\mathrm{Fe}, \mathrm{Cu}$ and $\mathrm{Ca}$. In other words, the left side

Table 4. Eigenvectors of correlation matrix

\begin{tabular}{lccc}
\hline \multicolumn{3}{c}{ Morphological traits and basic chemical composition } \\
\hline Variable & Factor 1 & Factor 2 & Factor 3 \\
\hline Fruit mass & 0.372073 & -0.139035 & 0.063029 \\
Fruit height & 0.352914 & -0.162106 & -0.074831 \\
Fruit width & 0.370019 & -0.128329 & 0.076983 \\
Fruit thickness & 0.363027 & -0.151759 & 0.091515 \\
Scar length & 0.325782 & -0.306902 & -0.028913 \\
Scar width & 0.327916 & -0.268453 & -0.017563 \\
Length of the longest & & & \\
intrusion of the seed & 0.095930 & -0.092293 & -0.330987 \\
coat into the kernel & & & \\
Water & -0.258779 & -0.433278 & -0.082648 \\
Ash & -0.151672 & -0.477908 & -0.037179 \\
Fat & 0.122875 & 0.167211 & 0.797827 \\
Protein & -0.284559 & -0.384322 & 0.085358 \\
Carbohydrate & 0.243725 & 0.385134 & -0.461955 \\
\hline \multirow{4}{*}{ Variable } & Mineral content & \\
\hline Cu & Factor 1 & Factor 2 & Factor 3 \\
Zn & 0.470513 & 0.172905 & -0.120400 \\
Fe & -0.024231 & 0.442282 & -0.686395 \\
Mn & 0.502412 & 0.166787 & -0.121357 \\
Na & 0.287629 & -0.316839 & 0.268374 \\
Ca & 0.366008 & 0.452790 & 0.167308 \\
Mg & 0.481620 & -0.128915 & 0.202130 \\
$\mathrm{~K}$ & 0.261070 & -0.481694 & -0.338747 \\
\hline & 0.093833 & -0.438884 & -0.493979 \\
\hline & & \\
\hline
\end{tabular}
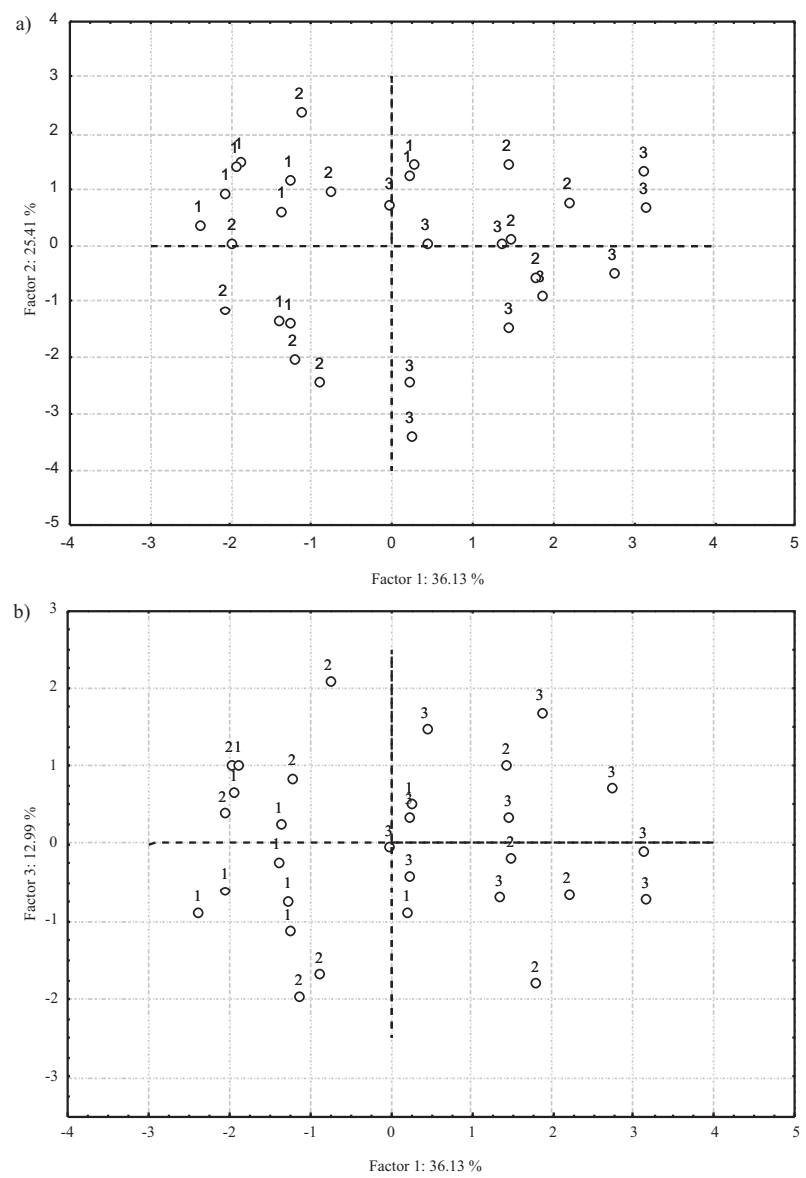

Fig. 3. PC analysis based on the mineral content: a) score plot of the chestnut samples projected on the space of PC1 vs. PC2, and b) score plot of the chestnut samples projected on the space of PC1 vs. PC3. (1='Lovran Marron', 2=Marušnjak, and 3=Učka population)

of the diagram contains samples with a lower mass fraction of the above-mentioned mineral substances than those on the right side. The second principal component, which accounts for $25.4 \%$ of variability, separates the samples with high $\mathrm{Mg}$ content, which is highly negatively correlated with it, from the samples with high $\mathrm{Na}$ and $\mathrm{Zn}$ content, which is highly positively correlated with the same principal component. The third principal component accounts for $13.0 \%$ of the overall variance and is negatively correlated with $\mathrm{Zn}$ content.

\section{Discussion}

Appreciable qualities of sweet chestnuts are: large nut size (for fresh market and candying, i.e. marron glacé), easy peeling (for fresh market and processing), low percentage of penetration of the seed coat into the kernel and monoembryony (for fresh market). According to the average mass, one kilogram of the 'Lovran Marron' fruits contains 80 fruits, which classifies them as large, bordering on medium large (68), in other words, they could be used for candying. Nowadays the majority of the fruits are sold for the fresh market. One fruit contains one seed each, i.e. no double seeds were observed, and the degree 
of the intrusion of the seed coat into the kernel is medium. Traditionally, the 'Lovran Marron' fruits are easily peeled. The colour of the fruit is reddish brown, with slightly protruding, longitudinal, dark stripes. This variety is justifiably called marron, according to both Italian and French criteria (15). As all of the sampled trees of the 'Lovran Marron' had previously been genotyped, i.e. it was verified that they belong to the same genotype (23), the result that the greatest variability in the majority of the morphological characteristics among trees was found in the sweet chestnut trees from the natural population and the smallest in the 'Lovran Marron' is expected. However, at the same time it was shown that the variability of fruits within a tree is highest in the 'Lovran Marron'. The Marušnjak trees mostly exhibit intermediate morphological characteristics of fruits in comparison with 'Lovran Marron' and trees from the natural populations, which is also expected, because those plants were grown from the seeds of 'Lovran Marron' obtained from free pollination. Plantations of the 'Lovran Marron', with a smaller share of the Marušnjak trees, are very close to the natural population of the sweet chestnut on Mount Učka or are incorporated in it.

Chestnuts have a low fat content, are rich in essential fatty acids, have a moderate but high quality protein content, are poor in $\mathrm{Na}$ and rich in $\mathrm{K}(2)$. They are also a good source of $\mathrm{Mg}, \mathrm{Fe}, \mathrm{Mn}$ and $\mathrm{Cu}(48)$. According to several studies $(24,29,31,40,48,49)$ chemical composition of chestnut fruits varies by cultivar (genotype) and by environmental factors (climatic conditions, soil characteristics and production practices).

The average mass fraction of water in the fruits of the 'Lovran Marron' (56.7 g per $100 \mathrm{~g}$ ) is in line with the data published for other sweet chestnut cultivars, which ranges from 40 to $60 \%$ of water $(25,31,36,40,46-48,50,51,54,69$, 70). According to Breisch (71) the water content of chestnuts should be between 49 and $60 \%$ for an adequate conservation. 'Lovran Marron' showed suitable water content for conservation.

The fat content of the 'Lovran Marron' is $2.55 \mathrm{~g}$ per $100 \mathrm{~g}$ of dry mass $(\mathrm{dm})$ on average; this result is within the range reported by Borges et al. $(48,49)$ and De La Montaña Míguelez et al. (31) of 1.26-3.50 g per $100 \mathrm{~g} \mathrm{dm}$. Average fat content in this work (in $\mathrm{g}$ per $100 \mathrm{~g} \mathrm{dm}$ ) is higher than that obtained by Ertürk et al. (52) 1.09, Ferreira-Cardoso et al. (51) 1.3 and Barreira et al. (46) 1.71. Somewhat greater average fat content ( $\mathrm{g}$ per $100 \mathrm{~g} \mathrm{dm}$ ) is reported by Dinis et al. (50) for the variety 'Judia' from the Trás-os-Montes Region in Portugal (2.78), Pereira-Lorenzo et al. (40) for cultivars from six Spanish regions (3.0), Sacchetti et al. (25) for three Italian sweet chestnut ecotypes (3.04.64) and Bellini et al. (70) for 'Marrone del Mugello' from Italy (4.41).

The mean mass fraction of protein in 'Lovran Marron' fruit is $3.52 \mathrm{~g}$ per $100 \mathrm{~g} \mathrm{dm}$. Higher average protein content is reported by Sacchetti et al. (25), Cristofori et al. (26) and Bellini et al. (70) for Italian chestnut cultivars and ecotypes (4.18-8.12 g per $100 \mathrm{~g} \mathrm{dm}$ ), De La Montaña Míguelez et al. (31) and Pereira-Lorenzo et al. (40) for Spanish chestnut cultivars (4.5-9.6 g per $100 \mathrm{~g} \mathrm{dm}$ ), Ferreira-Cardoso et al. (51), Barreira et al. $(46,47)$ and Borges et al. (48) for Portuguese chestnut cultivars (4.87-12 g per $100 \mathrm{~g} \mathrm{dm}$ ) and Ertan (53) for chestnut cultivars and European-Japa- nese hybrids from the Nazilly region in Turkey (4.6 g per $100 \mathrm{~g} \mathrm{dm}$ ). Great differences in protein content are influenced by the genotype and different environmental conditions in which those cultivars grow.

Chestnut fruits are mainly composed of carbohydrates, primarily starch $(47,54,72-76)$. Sucrose is the main sugar present in the chestnut, and it is one of the most important parameters for the assessment of the commercial quality of chestnuts $(34,35)$. Total mass fraction of carbohydrates found in the 'Lovran Marron' ranged between 90.53 and $92.47 \mathrm{~g}$ per $100 \mathrm{~g} \mathrm{dm}$, with a mean value of 91.50 $\mathrm{g}$ per $100 \mathrm{~g} \mathrm{dm}$. These data are somewhat higher than those reported by Bellini et al. (70) for 'Marrone del Mugello' (86.76 g per $100 \mathrm{~g} \mathrm{dm}$ ), and by Ertürk et al. (52) for chestnut cultivars and European-Japanese hybrids (75.32$86.31 \mathrm{~g}$ per $100 \mathrm{~g} \mathrm{dm}$ ). Similar average values are given by Barreira et al. (46) for Portuguese chestnut cultivars: 'Aveleira' (90.19 g per $100 \mathrm{~g} \mathrm{dm})$, 'Boa Ventura' (91.63 g per $100 \mathrm{~g} \mathrm{dm})$, 'Judia' (90.15 g per $100 \mathrm{~g} \mathrm{dm}$ ), and 'Longal' (91.68 g per $100 \mathrm{~g} \mathrm{dm}$ ).

Ash content in the 'Lovran Marron' is $2.43 \mathrm{~g}$ per $100 \mathrm{~g}$ $\mathrm{dm}$ on average. According to the literature data, the average ash content in other cultivars of the sweet chestnut ranged from 1.02 to $3.22 \mathrm{~g}$ per $100 \mathrm{~g} \mathrm{dm}(25,31,36,40,46-$ 48,51,52).

Potassium is the most represented mineral in the fruits of the sweet chestnut. Potassium content varies significantly in different cultivars from the Mediterranean countries. The 'Lovran Marron' contains 1371.8 mg per $100 \mathrm{~g} \mathrm{dm}$ of $\mathrm{K}$ on average. Somewhat lower values are reported by Bellini et al. (70) in the Italian chestnut cultivar 'Marrone del Mugello' (800.6 mg per $100 \mathrm{~g} \mathrm{dm}$ ), Borges et al. (48) and Ferreira-Cardoso et al. (51) in Portuguese chestnut cultivars (473.0-1202.7 $\mathrm{mg}$ per $100 \mathrm{~g} \mathrm{dm}$ ) as well as by Pereira-Lorenzo et al. (40) and Peña-Méndez et al. (36) in Spanish chestnut cultivars (789.0-1201.4 mg per $100 \mathrm{~g}$ $\mathrm{dm})$.

The fruits of the 'Lovran Marron' have $76.3 \mathrm{mg}$ per $100 \mathrm{~g} \mathrm{dm}$ of $\mathrm{Mg}$ on average. These data are within the range reported by Borges et al. (48) and Ferreira-Cardoso et al. (51) for Portuguese chestnut cultivars (63.3-93.3 mg per $100 \mathrm{~g} \mathrm{dm}$ ), as well as by Pereira-Lorenzo et al. (40) and Peña-Méndez et al. (36) for Spanish chestnut cultivars (49.0-100.0 mg per $100 \mathrm{~g} \mathrm{dm}$ ). Smaller Mg content on average is reported by Bellini et al. (70) for the Italian chestnut cultivar 'Marrone del Mugello' (51.3 mg per $100 \mathrm{~g}$ $\mathrm{dm})$.

The average $\mathrm{Ca}$ and Na contents of the 'Lovran Marron' are generally higher than those reported by Borges et al. (48), Ferreira-Cardoso et al. (51), Pereira-Lorenzo et al. (40), Peña-Méndez et al. (36), Bellini et al. (70) and Sacchetti et al. (25) for Portuguese, Spanish and Italian chestnut cultivars. According to these authors, Ca content is within the range from 26.0 to $72.0 \mathrm{mg}$ per $100 \mathrm{~g} \mathrm{dm}$, and Na content from $0.76-26.0 \mathrm{mg}$ per $100 \mathrm{~g} \mathrm{dm}$.

Regarding micronutrients, Mn (2.14 mg per $100 \mathrm{~g}$ $\mathrm{dm}$ ) was the most abundant in the fruits of the 'Lovran Marron', followed by $\mathrm{Fe}, \mathrm{Zn}$ and $\mathrm{Cu}$ at 1.57, 1.53 and 1.04 $\mathrm{mg}$ per $100 \mathrm{~g} \mathrm{dm}$, respectively. A similar pattern was observed by Pereira-Lorenzo et al. (40), and Ferreira-Cardoso et al. (51). Smaller mass fractions of Mn and Fe were 
reported by Peña-Méndez et al. (36) in Spanish chestnut cultivars, and greater by Borges et al. (48) and Ferreira-Cardoso et al. (51) in Portuguese chestnut cultivars. Average $\mathrm{Zn}$ and $\mathrm{Cu}$ mass fractions are higher than those found by Ferreira-Cardoso et al. (51), Bellini et al. (70) and Peña-Méndez et al. (36), and lower than those reported by Borges et al. (48). The micronutrient mass fractions detected in this study are within the ranges reported by Pereira-Lorenzo et al. (40).

By comparing the chemical composition of the fruits of the 'Lovran Marron', the Marušnjak and the fruits from the Učka natural population, which grow in similar environmental conditions, we see that the Marušnjak fruits have an intermediate content of water, proteins, ash, carbohydrates, and macro- and microelements.

It is very important to preserve the valuable genotype of the 'Lovran Marron', as it is the only Croatian traditional cultivar of the sweet chestnut, grown in a relatively small area, under the specific conditions of the sub-Mediterranean climate, on northern and eastern exposures and in deep and washed out soil above the limestone base $(77,78)$. This genotype can potentially have special adaptive characteristics important for the conditions of changing climate, and also has great significance from the socioeconomic aspect and the promotion of the local identity of the entire Lovran area. Thus, for instance, in its logo, the Učka Nature Park has the fruits of the 'Lovran Marron', and every fall in Lovran the traditional tourism event Marunada takes place, during which local chestnut products have the central role. However, many plantations are already old and neglected, and there is also the danger, especially due to the vulnerability of the 'Lovran Marron' to the chestnut blight (21) and increasing damage caused by the chestnut gall wasp, of this traditional cultivar gradually being replaced by the more resistant European-Japanese hybrids, as for instance 'Bouche de Bétizac' (79). Similar danger for the traditional Italian cultivars is mentioned by Torello Marinoni et al. (28).

\section{Conclusions}

The traditional Croatian variety 'Lovran Marron' has desirable qualitative and quantitative fruit characteristics. According to the average mass, the fruits of the 'Lovran Marron' are large, bordering on medium large ( 80 fruits per $\mathrm{kg}$ ) and they could be used for candying. Each fruit contains one seed and the degree of the intrusion of the seed coat into the kernel is medium. The colour of the fruit is reddish brown, with slightly protruding, longitudinal, dark stripes. The name marron is justified for this variety, according to both Italian and French criteria. 'Lovran Marron' had the smallest mass fractions on average of $\mathrm{K}, \mathrm{Mg}, \mathrm{Ca}, \mathrm{Na}, \mathrm{Mn}, \mathrm{Cu}$ and Fe. The highest mass fractions on average of these macro- and microelements were characteristic of the trees from the natural population. The highest average content of carbohydrates was recorded in the 'Lovran Marron' and the lowest in the fruits from the natural population. The Marušnjak trees exhibit intermediate characteristics of fruit mass, fruit height, fruit width, fruit thickness, scar width, fruit height/width ratio, fruit thickness/height ratio, and water, protein, ash, carbohydrates, and macro- and microelement content, in comparison with 'Lovran Marron' and trees from the natural populations. The mass fractions of $\mathrm{Cd}$ and $\mathrm{Pb}$ were lower in all samples than the maximum allowed amounts in the sweet chestnut fruits, which indicates an unpolluted environment. It is very important to preserve the valuable genotype of the 'Lovran Marron', as it is the only Croatian traditional cultivar of the sweet chestnut, grown in a relatively small area, under specific conditions.

\section{Acknowledgement}

The study was financed by the ADRIS Foundation, with a donation for the project on the Specification of the 'Lovran Marron' Fruits. We are grateful to marron growers for providing their help and allowing us to conduct the study on their private plantations.

\section{References}

1. Bounous G. The chestnut: a multipurpose resource for the new millennium. Acta Hortic. 2005;693:33-40. http://dx.doi.org/10.17660/ActaHortic.2005.693.1

2. Bounous G, Botta R, Beccaro GL, Mellano MG. The chestnut. Biodiversity of the Capanne di Marcarolo. Bosio, Italy: Ecomuseo di Cascina Moglioni; 2005 (in Italian).

3. Fernández-López J, Pereira-Lorenzo S. Index and distribution of chestnut (Castanea sativa Mill.) traditional cultivars in Galicia. Madrid, Spain: Instituto Nacional de Investigación y Technología Agraria y Alimentaria; 1993 (in Spanish).

4. Conedera M, Müller-Starck G, Fineschi S. Genetic characterization of cultivated varieties of European chestnut (Castanea sativa Mill.) in Southern Switzerland. I. Inventory of chestnut varieties: history and perspectives. In: Anognozzi $\mathrm{E}$, editor. Proceedings of the International Congress on Chestnut; October 20-23; Spoleto, Italy. Spoleto, Italy: Tipografia Litografia Spoletina; 1994. pp. 299-302.

5. Hennion B. France. In: Avanzato D, editor. Following chestnut footprints (Castanea spp.) - Cultivation and culture, folklore and history, traditions and uses. Scripta Horticulturae No. 9. Leuven, Belgium; International Society for Horticultural Science (ISHS); 2009. pp. 44-7.

6. Bounous G. Italy. In: Avanzato D, editor. Following chestnut footprints (Castanea spp.) - Cultivation and culture, folklore and history, traditions and uses. Scripta Horticulturae No. 9. Leuven, Belgium; International Society for Horticultural Science (ISHS); 2009. pp. 72-84.

7. Bouffier VA, Maurer WD. Germany. In: Avanzato D, editor. Following chestnut footprints (Castanea spp.) - Cultivation and culture, folklore and history, traditions and uses. Scripta Horticulturae No. 9. Leuven, Belgium; International Society for Horticultural Science (ISHS); 2009. pp. 53-62.

8. Gomes-Laranjo J, Peixoto F, Costa R, Ferreira-Cardoso J. Portugal. In: Avanzato D, editor. Following chestnut footprints (Castanea spp.) - Cultivation and culture, folklore and history, traditions and uses. Scripta Horticulturae No. 9. Leuven, Belgium; International Society for Horticultural Science (ISHS); 2009. pp. 106-11.

9. Pereira-Lorenzo S, Ramos-Cabrer AM, Díaz-Hernández B, Ascasíbar-Errasti J, Sau F. Spanish chestnut cultivars. Hort Sci. 2001;36:344-7.

10. Pereira-Lorenzo S, Ríos D, González-Pérez J, Cubas F, Perdomo A, Calzadilla C, Ramos-Cabrer AM. Chestnut cultivars on the Canary Islands. For Snow Landsc Res. 2001;76:445-50. 
11. Pereira-Lorenzo S, Díaz-Hernández MB, Ramos-Cabrer AM. Spain. In: Avanzato D, editor. Following chestnut footprints (Castanea spp.) - Cultivation and culture, folklore and history, traditions and uses. Scripta Horticulturae No. 9. Leuven, Belgium; International Society for Horticultural Science (ISHS); 2009. pp. 134-41.

12. Martín MA, Moral, A, Martín LM, Alvarez JB. The genetic resources of European sweet chestnut (Castanea sativa Miller) in Andalusia, Spain. Genet Resour Crop Ev. 2007;54:37987. http://dx.doi.org/10.1007/s10722-005-5969-z

13. Martín MA, Alvarez JB, Martín LM, Mattioni C, Cherubini M, Villani F, Ruiz JC. Traditional chestnut cultivars in Southern Spain: a case of endangered genetic resources. Acta Hortic. 2010;866:143-50. http://dx.doi.org/10.17660/ActaHortic.2010.866.15

14. Soylu A, Serdar Ü, Ertan E, Mert C. Turkey. In: Avanzato D, editor. Following chestnut footprints (Castanea spp.) - Cultivation and culture, folklore and history, traditions and uses. Scripta Horticulturae No. 9. Leuven, Belgium; International Society for Horticultural Science (ISHS); 2009. pp. 155-60.

15. Bounous G. Sustainable management of the chestnut plantations to obtain quality produce. Acta Hortic. 2009;815:19-24. http://dx.doi.org/10.17660/ActaHortic.2009.815.1

16. Medak J, Idžojtić M, Novak-Agbaba S, Ćurković-Perica M, Mujić I, Poljak I, Juretić D, Prgomet Ž. Croatia. In: Avanzato D, editor. Following chestnut footprints (Castanea spp.) Cultivation and culture, folklore and history, traditions and uses. Scripta Horticulturae No. 9. Leuven, Belgium; International Society for Horticultural Science (ISHS); 2009. pp. 403.

17. Arnaud MT, Chassany JP, Dejean R, Ribart J, Queno L. Economic and ecological consequences of the disappearance of traditional practices related to chestnut groves. J Environ Manage. 1997;49:373-91.

http://dx.doi.org/10.1006/jema.1995.0120

18. Agnoletti $\mathrm{M}$. The degradation of traditional landscape in a mountain area of Tuscany during the 19th and 20th centuries: implications for biodiversity and sustainable management. Forest Ecol Manag. 2007;249:5-17. http://dx.doi.org/10.1016/j.foreco.2007.05.032

19. Beccaro GL, Mellano MG, Barrel A, Trasino C. Restoration of old and abandoned chestnut plantations in Northern Italy. Acta Hortic. 2009;815:185-90. http://dx.doi.org/10.17660/ActaHortic.2009.815.24

20. Fernández-López J, Alía R. EUFORGEN technical guidelines for genetic conservation and use for chestnut (Castanea sativa). Rome, Italy: International Plant Genetic Resources Institute (IPGRI); 2003. Available from: http://www.euforgen.org/ fileadmin/bioversity/publications/pdfs/EUFORGEN/924_ Technical_guidelines_for_genetic_conservation_and_use_ for_chestnut_Castanea_sativa_.pdf.

21. Ježić M, Krstin Lj, Poljak I, Liber Z, Idžojtić M, Jelić M, et al. Castanea sativa: genotype-dependent recovery from chestnut blight. Tree Genet Genomes. 2014;10:101-10. http://dx.doi.org/10.1007/s11295-013-0667-z

22. Matošević D, Pernek M, Hrašovec B. First record of Oriental chestnut gall wasp (Dryocosmus kuriphilus) in Croatia. Šumarski list. 2010;134:497-502 (in Croatian).

23. Idžojtić M, Zebec M, Poljak I, Šatović Z, Liber Z. Analysis of the genetic diversity of 'Lovran Marron' using microsatellite markers. Šumarski list. 2012;136:577-85 (in Croatian).

24. Botta R, Akkak A, Guaraldo P, Bounous G. Genetic characterization and nut quality of chestnut cultivars from Piemonte (Italy). Acta Hortic. 2005;693:395-402. http://dx.doi.org/10.17660/ActaHortic.2005.693.49

25. Sacchetti G, Neri L, Dimitri G, Mastrocola D. Chemical composition and functional properties of three sweet chestnut
(Castanea sativa Mill.) ecotypes from Italy. Acta Hortic. 2009; 41-6. http://dx.doi.org/10.17660/ActaHortic.2009.844.4

26. Cristofori V, Muganu M, Graziosi P, Beratazza G, Bignami C. Comparison of nut traits and quality evaluation of chestnut (Castanea sativa Mill.) germplasm in Latium Region (Central Italy). Acta Hortic. 2009;815:133-40. http://dx.doi.org/10.17660/ActaHortic.2009.815.17

27. Neri L, Dimitri G, Sacchetti G. Chemical composition and antioxidant activity of cured chestnuts from three sweet chestnut (Castanea sativa Mill.) ecotypes from Italy. J Food Compos Anal. 2010;23:23-9. http://dx.doi.org/10.1016/j.jfca.2009.03.002

28. Torello Marinoni D, Akkak A, Beltramo C, Guaraldo P, Boccacci $\mathrm{P}$, Bounous $\mathrm{G}$, et al. Genetic and morphological characterization of chestnut (Castanea sativa Mill.) germplasm in Piedmont (north-western Italy). Tree Genet Genomes. 2013; 9:1017-30. http://dx.doi.org/10.1007/s11295-013-0613-0

29. Silvanini A, Dall'Asta C, Morrone L, Cirlini M, Beghè D, Fabbri A, Ganino T. Altitude effects on fruit morphology and flour composition of two chestnut cultivars. Sci Hortic. 2014; 176:311-18. http://dx.doi.org/10.1016/j.scienta.2014.07.008

30. Álvarez-Álvarez P, Barrio-Anta M, Diéguez-Aranda U. Differentiation of sweet chestnut (Castanea sativa Mill.) cultivars by leaf, nut and burr dimensions. Forestry. 2006;79:14958. http://dx.doi.org/10.1093/forestry/cpl006

31. De La Montaña Míguelez J, Míguez Bernárdez M, García Queijeiro JM. Composition of varieties of chestnuts from Galicia (Spain). Food Chem. 2004;84:401-4. http://dx.doi.org/10.1016/S0308-8146(03)00249-8

32. Furones $\mathrm{P}$, Fernández-López J. Differentiation among chestnut cultivars using adaptive and morphological traits. Acta Hortic. 2005;693:497-504. http://dx.doi.org/10.17660/ActaHortic.2005.693.64

33. Furones-Pérez P, Fernández-López J. Morphological and phenological description of 38 sweet chestnut cultivars (Castanea sativa Miller) in a contemporary collection. Span J Agric Res. 2009;7:829-43. http://dx.doi.org/10.5424/sjar/2009074-1097

34. Hernández Suárez M, Rodríguez Galdón B, Ríos Mesa D, Díaz Romero C, Rodríguez Rodríguez E. Sugars, organic acids and total phenols in varieties of chestnut fruits from Tenerife (Spain). Food Nutr Sci. 2012;3:705-15. http://dx.doi.org/10.4236/fns.2012.36096

35. Míguez Bernárdez M, De la Montaña Miguélez J, García Queijeiro. HPLC determination of sugars in varieties of chestnut fruits from Galicia (Spain). J Food Comp Anal. 2004;17:63-7. http://dx.doi.org/10.1016/S0889-1575(03)00093-0

36. Peña-Méndez EM, Hernández-Suárez M, Díaz-Romero $C$, Rodríguez-Rodríguez E. Characterization of various chestnut cultivars by means of chemometrics approach. Food Chem. 2008;107:537-44.

http://dx.doi.org/10.1016/j.foodchem.2007.08.024

37. Pereira-Lorenzo S, Díaz-Hernández MB, Ramos-Cabrer AM. Use of highly discriminating morphological characters and isozymes in the study of Spanish chestnut cultivars. J Am Soc Hortic Sci. 2006;131:770-9.

38. Pereira-Lorenzo S, Fernández-López J, Morengo-González J. Variability and grouping of Northwestern Spanish chestnut cultivars. I. Morphological traits. J Am Soc Hortic Sci. 1996; 121:183-9.

39. Pereira-Lorenzo S, Fernández-López J. Description of 80 cultivars and 36 clonal selections of chestnut (Castanea sativa Mill.) from Northwestern Spain. Fruit Varieties J. 1997;51:13-27. 
40. Pereira-Lorenzo S, Ramos-Cabrer AM, Díaz-Hernández MB, Ciordia-Ara M, Ríos-Mesa D. Chemical composition of chestnut cultivars from Spain. Sci Hortic. 2006;107:306-14. http://dx.doi.org/10.1016/j.scienta.2005.08.008

41. Queijeiro JM, De La Montaña J, Míguez M. Identification and morphological description of cultivars of chestnut (Castanea sativa Mill.) of the region of Verín-Monterrei (Ourense, Spain). J Am Pom Soc. 2006;60:37-45.

42. Ramos-Cabrer AM, Pereira-Lorenzo S. Genetic relationship between Castanea sativa Mill. Trees from north-western to south Spain based on morphological traits and isoenzymes. Genet Resour Crop Ev. 2005;52;879-90. http://dx.doi.org/10.1007/s10722-003-6094-5

43. Müller-Starck G, Conedera M, Fineschi S. Genetic characterization of cultivated varieties of European chestnut (Castanea sativa Mill.) in Southern Switzerland. II. Genetic inventory based on enzyme gene markers. In: Anognozzi E, editor. Proceedings of the International Congress on Chestnut; October 20-23; Spoleto, Italy. Spoleto, Italy: Tipografia Litografia Spoletina; 1994. pp. 303-7.

44. Künsch U, Schärer H, Patrian B, Hurter J, Conedera M, Sassella A, et al. Quality assessment of chestnut fruits. Acta Hortic. 1999;494:119-27.

http://dx.doi.org/10.17660/ActaHortic.1999.494.17

45. Gobbin D, Hohl L, Conza L, Jermini M, Gessler C, Conedera M. Microsatellite-based characterization of the Castanea sativa cultivar heritage of southern Switzerland. Genome. 2007; 50:1089-103.

http://dx.doi.org/10.1139/G07-086

46. Barreira JCM, Casal S, Ferreira ICFR, Oliveira MBPP, Pereira JA. Nutritional, fatty acid and triacylglycerol profiles of Castanea sativa Mill. cultivars: a compositional and chemometric approach. J Agric Food Chem. 2009;57:2836-42. http://dx.doi.org/10.1021/jf803754u

47. Barreira JCM, Casal S, Ferreira ICFR, Peres AM, Pereira JA, Oliveira MBPP. Chemical characterization of chestnut cultivars from three consecutive years: chemometrics and contribution for authentication. Food Chem Toxicol. 2012;50:231117. http://dx.doi.org/10.1016/j.fct.2012.04.008

48. Borges O, Gonçalves B, de Carvalho JLS, Correia P, Silva AP. Nutritional quality of chestnut (Castanea sativa Mill.) cultivars from Portugal. Food Chem. 2008;106:976-84. http://dx.doi.org/10.1016/j.foodchem.2007.07.011

49. Borges OP, Carvalho JS, Correia PR, Silva AP. Lipid and fatty acids profiles of Castanea sativa Mill. chestnuts of 17 native Portuguese cultivars. J Food Compos Anal. 2007;20:80-9. http://dx.doi.org/10.1016/j.jfca.2006.07.008

50. Dinis LT, Ferreira-Cardoso J, Peixoto F, Costa R, GomesLaranjo J. Study of morphological and chemical diversity in chestnut trees (var. 'Judia') as a function of temperature sum. CyTA J Food. 2011;9:192-9. http://dx.doi.org/10.1080/19476337.2010.512394

51. Ferreira-Cardoso JV, Torres-Pereira JMG, Sequeira CA. Effect of year and cultivar on chemical composition of chestnuts from northeastern Portugal. Acta Hortic. 2005;693:271-8. http://dx.doi.org/10.17660/ActaHortic.2005.693.33

52. Ertürk Ü, Mert C, Soylu A. Chemical composition of fruits of some important chestnut cultivars. Braz Arch Biol Technol. 2006;49:183-8. http://dx.doi.org/10.1590/S1516-89132006000300001

53. Ertan E. Variability in leaf and fruit morphology and in fruit composition of chestnuts (Castanea sativa Mill.) in the Nazilli region of Turkey. Genet Resour Crop Ev. 2007;54:691-9. http://dx.doi.org/10.1007/s10722-006-0020-6

54. De Vasconcelos MCBM, Bennett RN, Rosa EAS, FerreiraCardoso JV. Composition of European chestnut (Castanea sativa Mill.) and association with health effects: fresh and processed products. J Sci Food Agric. 2010;90:1578-89. http://dx.doi.org/10.1002/jsfa.4016

55. Poljak I, Idžojtić M, Zebec M, Perković N. The variability of European sweet chestnut (Castanea sativa Mill.) in the region of northwest Croatia according to morphology of fruits. Sumarski list. 2012;136:479-89 (in Croatian).

56. UPOV, TG/124/3. Guidelines for the conduct of tests for distinctness, homogeneity and stability. Chestnut (Castanea sativa Mill.). Geneve, Switzerland:International Union for the Protection of New Varieties of Plants; 1989. Available from: http://www.upov.int/edocs/tgdocs/en/tg124.pdf.

57. Oraguzie NC, McNeil DL, Paterson AM, Chapman H. Comparison of RAPD and morpho-nut markers for revealing genetic relationships between chestnut species (Castanea spp.) and New Zealand chestnut selections. New Zeal J Crop Hort Sci. 1998;26:109-15. http://dx.doi.org/10.1080/01140671.1998.9514047

58. Oraguzie NC, Paterson AM, McNeil DL. Origin and relationships of New Zealand chestnut (Castanea sp. Fagaceae) selections reflect patterns of graft failure. Plant Syst Evol. 1999;218:193-204. http://dx.doi.org/10.1007/BF01089227

59. Martín MA, Alvarez JB, Mattioni C, Cherubini M, Villani F, Martín LM. On-farm conservation of sweet chestnut (Castanea sativa Mill.) in Andalusia. J Agr Sci Technol. 2011;5:1549.

60. AOAC Official Method 925.40. Moisture in nuts and nut products. Washington, USA: AOAC International; 1995.

61. AOAC Official Method 950.49. Ash of nuts and nut products. Washington, USA: AOAC International; 1995.

62. AOAC Official Method 950.48. Protein (crude) in nuts and nut products. Washington, USA: AOAC International; 1995.

63. AOAC Official Method 948.22. Fat (crude) in nuts and nut products. Washington, USA: AOAC International; 2000.

64. Oliveira I, Sousa A, Morais JS, Ferreira ICFR, Bento A, Estevinho L, Pereira JA. Chemical composition, and antioxidant and antimicrobial activities of three hazelnut (Corylus avellana L.) cultivars. Food Chem Toxicol. 2008;46:1801-7. http://dx.doi.org/10.1016/j.fct.2008.01.026

65. Pereira JA, Oliveira I, Sousa A, Ferreira ICFR, Bento A, Estevinho L. Bioactive properties and chemical composition of six walnut (Juglans regia L.) cultivars. Food Chem Toxicol. 2008;46:2103-11. http://dx.doi.org/10.1016/j.fct.2008.02.002

66. Sokal RR, Rohlf FJ. Biometry. San Francisco, USA: Freeman and Co; 1981.

67. STATISTICA, v. 8.0, StatSoft, Inc, Tulsa, OK, USA; 2001. Available from: http://www.statsoft.com.

68. Bounous G, Barrel A, Beccaro G, Lovisolo C, Gomes Pereira JA. Inventory of chestnut research, germplasm and references. FAO-CIHEAM REU Technical Series. 2001;65:1-174.

69. Korel F, Balaban MÖ. Chemical composition and health aspects of chestnut (Castanea spp.), In: Alasalvar C, Shahidi F, editors. Tree nuts: composition, phytochemicals and health effects. Boca Raton, FL, USA: CRC Press Taylor and Francis Group; 2008. http://dx.doi.org/10.1201/9781420019391.ch1

70. Bellini E, Giordani E, Marinelli C, Perucca B. Marrone del Mugello PGI chestnut nutritional and organoleptic quality. Acta Hortic. 2005;693:97-102. http://dx.doi.org/10.17660/ActaHortic.2005.693.9

71. Breisch H. Harvesting, storage and processing of chestnuts in France and Italy. In: Anognozzi E, editor. Proceedings of the International Congress on Chestnut; October 20-23; Spoleto, Italy. Spoleto, Italy: Tipografia Litografia Spoletina; 1994. pp. 429-36. 
72. Chenlo F, Moreira R, Prieto DM, Torres MD. Desorption isotherms and net isosteric heat of chestnut flour and starch. Food Bioprocess Technol. 2011;4:1497-504. http://dx.doi.org/10.1007/s11947-009-0239-2

73. Moreira R, Chenlo F, Torres MD, Prieto DM. Technological assessment of chestnut flour doughs regarding to doughs from other commercial flours and formulations. Food Bioprocess Technol. 2012;5:2301-10.

http://dx.doi.org/10.1007/s11947-011-0524-8

74. Torres MD, Moreira R, Chenlo F, Morel MH, Barron C. Physicochemical and structural properties of starch isolated from fresh and dried chestnuts and chestnut flour. Food Technol Biotechnol. 2014;52:135-9.

75. Cruz BR, Abraão AS, Lemos AM, Nunes FM. Chemical composition and functional properties of native chestnut starch (Castanea sativa Mill). Carbohydr Polym. 2013;94:594-602. http://dx.doi.org/10.1016/j.carbpol.2012.12.060
76. Silva AP, Oliveira I, Silva ME, Guedes CM, Borges O, Magalhães B, Gonçalves B. Starch characterization in seven raw, boiled and roasted chestnuts (Castanea sativa Mill.) cultivars from Portugal. J Food Sci Tech Mys. 2016;53:348-58. http://dx.doi.org/10.1007/s13197-015-2047-1

77. Anić, M. Forest vegetation of Istria with Trieste, Gorica and south-western Carniola. Šumarski list. 1945;69:13-23 (in Croatian).

78. Medak J. Forest associations and habitats of sweet chestnut (Castanea sativa Mill.) in Croatia [PhD Thesis]. Zagreb, Croatia: Faculty of Forestry, University of Zagreb; 2009 (in Croatian).

79. Sartor C, Botta R, Mellano MG, Beccaro GL, Bounous G, Torello Marinoni D, et al. Evaluation of susceptibility to Dryocosmus kuriphilus Yasumatsu (Hymenoptera: Cynipidae) in Castanea sativa Miller and hybrid cultivars. Acta Hortic. 2009;815:289-97.

http://dx.doi.org/10.17660/ActaHortic.2009.815.38 